\title{
Mediterranean Landscape Re-Greening at the Expense of South American Agricultural Expansion
}

\author{
Jaime Martínez-Valderrama ${ }^{1, *}$, María E. Sanjuán ${ }^{2}$, Gabriel del Barrio ${ }^{2}\left(\right.$, Emilio Guirado ${ }^{1}\left(\mathbb{D}\right.$, Alberto Ruiz $^{2}$ and \\ Fernando T. Maestre 1,3 (D) \\ 1 Instituto Multidisciplinar para el Estudio del Medio "Ramón Margalef", Universidad de Alicante, \\ Carretera de San Vicente del Raspeig s/n, 03690 San Vicente del Raspeig, Spain; emilio.guirado@ua.es (E.G.); \\ ft.maestre@ua.es (F.T.M.) \\ 2 Estación Experimental de Zonas Áridas, CSIC, Ctra. Sacramento s/n, La Cañada, 04120 Almería, Spain; \\ marieta@eeza.csic.es (M.E.S.); gabriel@eeza.csic.es (G.d.B.); aruiz@eeza.csic.es (A.R.) \\ 3 Departamento de Ecología, Universidad de Alicante, Carretera de San Vicente del Raspeig s/n, \\ 03690 San Vicente del Raspeig, Spain \\ * Correspondence: jaime.mv@ua.es
}

Citation: Martínez-Valderrama, J.;

Sanjuán, M.E.; del Barrio, G.; Guirado,

E.; Ruiz, A.; Maestre, F.T.

Mediterranean Landscape

Re-Greening at the Expense of South

American Agricultural Expansion.

Land 2021, 10, 204. https://doi.org/

10.3390/land10020204

Academic Editor: Marta Debolini

Received: 8 January 2021

Accepted: 13 February 2021

Published: 17 February 2021

Publisher's Note: MDPI stays neutral with regard to jurisdictional claims in published maps and institutional affiliations.

Copyright: (c) 2021 by the authors. Licensee MDPI, Basel, Switzerland. This article is an open access article distributed under the terms and conditions of the Creative Commons Attribution (CC BY) license (https:// creativecommons.org/licenses/by/ $4.0 /)$

\begin{abstract}
The stabling of livestock farming implies changes in both local ecosystems (regeneration of forest stands via reduced grazing) and those located thousands of kilometers away (deforestation to produce grain for feeding livestock). Despite their importance, these externalities are poorly known. Here we evaluated how the intensification and confinement of livestock in Spain has affected forest surface changes there and in South America, the largest provider of soybeans for animal feed to the European Union. For this purpose, we have used Spanish soybean import data from Brazil, Paraguay and Argentina and a land condition map of Spain. The area of secondary forest in Spain that has regenerated as a result of livestock stabling has been $\sim 7000$ kha for the decade 2000-2010. In the same period, 1220 kha of high value South American ecosystems (e.g., Chaco dry Forest, Amazonian rainforest or Cerrado) have been deforested. While these figures may offer a favorable interpretation of the current industrial livestock production, it is not possible to speak of compensation when comparing the destruction of well-structured ecosystems, such as primary South American forests, with the creation of secondary forest landscapes in Spain, which are also prone to wildfires. Our results highlight how evaluating land use change policies at a national or regional level is an incomplete exercise in our highly telecoupled and globalized world.
\end{abstract}

Keywords: livestock; feeds; deforestation; re-greening; soybean; telecoupling

\section{Introduction}

Globalization, defined as "the increased connectivity and interdependence among people worldwide and the intensified consciousness of the world as a whole" [1] largely defines how we live and use land today. The drivers of this phenomenon, which include trade, transport, technology and consumption, are not new but their scale and speed certainly are [2]. In the agricultural sphere this means that nearly one third of arable land use is embedded in international trade [3]. The distancing from production and consumption centers is evidenced by the consumption-based land use inventory [4], i.e., the proportion of domestic land used within the territory of a country compared to land used outside a country's territory. The World average share is $73-27 \%$ but in some island countries the balance shifts to a stunning $8-92 \%$, as in the case of Japan, or a $20-80 \%$ for the UK. In Europe the foreign land is, on average, above 50\%, with 13-87\% in Germany, $33-67 \%$ in France and 37-63\% in Spain [4].

One of the most important consequences of the globalization of the primary sector is that a country's consumption patterns can deeply alter production ecosystems at distant locations, within and across sectors [5]. This is especially noticeable in countries that 
are committed to implementing sustainable agricultural production but do not apply the same standards to agricultural products coming from abroad [6]. The livestock industry, which revolves around the use of compound feed, is a good example of global telecoupling, i.e. global supply chains involving large geographical distances and creating environmental pressures (including deforestation and other types of land conversions) remote from the places where the consumption of goods and services take place [4]. Driven by the global increase in the demand of meat [7], extensive livestock grazing is being replaced by increasingly intensive systems worldwide, where animals become stabled and detached from the land $[3,8]$. This change transfers some of the environmental impacts of this activity to the countries producing the raw materials used in animal feeds $[9,10]$. The cornerstone of this change relies in the production of feed. Nearly two thirds of cereal production in the European Union are used for animal feed [11], and globally the figure is 36\% [12]. Additionally, around three-quarters of soy worldwide is used for animal feed [13,14]. This dependence is expected to increase; by 2050 annual cereal and soybean production are forecasted to increase by $940 \mathrm{Mt}(+46 \%)$ and $390 \mathrm{Mt}(+80 \%)$, respectively [7]. In this way livestock remains the world's largest user of land, but its use has shifted steadily from grazing to the consumption of feed crops [15].

Soybean trade exemplifies the environmental and socio-economic impact of global markets and agricultural policies [9]. It represents an essential change in the destiny of food that, instead of being diverted directly for human consumption, is used to feed livestock [16,17]. This 'diet gap', i.e. human-edible crop calories that do not end up in the food system [18], 'represents a net drain on the world's potential food supply' [19]. Soy imports into the European Union to feed its livestock from South America $[9,20]$ (27.7 Mt in 2012 [14]) entail the expansion of soybean cultivation, promoting a cascade of effects there. On the one hand, soybean fields occupy former rangelands, forcing the displacement of livestock and the clearing of new areas for animals to graze [21], many of them previously occupied by valuable primary forests $[22,23]$. The result is the destruction of natural ecosystems of great ecological value such as the Gran Chaco in Argentina and Paraguay [24-26], or the Amazon rainforest in Brazil [9,14]. Deforestation has been estimated at $97 \mathrm{~m}^{2} \cdot \mathrm{t} \mathrm{soy}^{-1} \cdot \mathrm{year}^{-1}$ [23]. On the other hand, it favors the imposition of monocultures cropped following intensive agricultural practices, which have serious environmental [27], and social [28] consequences.

Within the EU, the case of livestock intensification in Spain is particularly relevant when exploring the externalities and land impacts associated to livestock farming. In Spain, livestock breeding has been continuously growing since 1900 [29]. Over the last decades, and coinciding with the rural exodus to the cities of the 1960's [29-31], extensive livestock farming has practically disappeared as a result of the progressive confinement of livestock farming, which has made Spain the leading European producer of animal feed [32] (Figure 1A). There have also been changes in the composition of the livestock during this period (Figure 1B). The mixed use of breeds, which were used for work, produced manure that served to fertilize the pastures on which they fed (a boast of the circular economy that we pursue today) and produced different types of high-protein food, have gradually become marginal $[33,34]$. Likewise, the number of monogastric animals has increased significantly. According to official statistics [35], the Ruminants-Monogastric ratio (measured in Livestock Standard Units, LSU) has changed in Spain from 52-48 in 1984 to 29-71 in 2018. Particularly noteworthy is the growth of pig farming, which with 4641 thousand tons in 2019 represents $64.7 \%$ of the country's meat production (Figure 1C).

The change in livestock production to more efficient monogastric animals that has taken place in Spain has been accompanied by the rise in landless production systems. In 2013 at least $3.8 \times 10^{6}$ LSU live in landless farms and another $1.4 \times 10^{6}$ LSU live in farms with less than $5 \mathrm{ha}$; only one third $\left(4.7 \times 10^{6}\right)$ of the livestock $\left(14.5 \times 10^{6} \mathrm{LSU}\right)$ live in farms with more than 50 ha [36]. The trend is well reflected by the evolution of the economic size of farms, as measured by the standard economic output [37]. As can be seen in Figure 1D, the number of farms has decreased over time for all categories except the 
largest (over 100,000 euro; red line). These macro farms account for almost 80\% $\left(11.4 \times 10^{6}\right.$

LSU in 2013) of all the livestock in Spain.

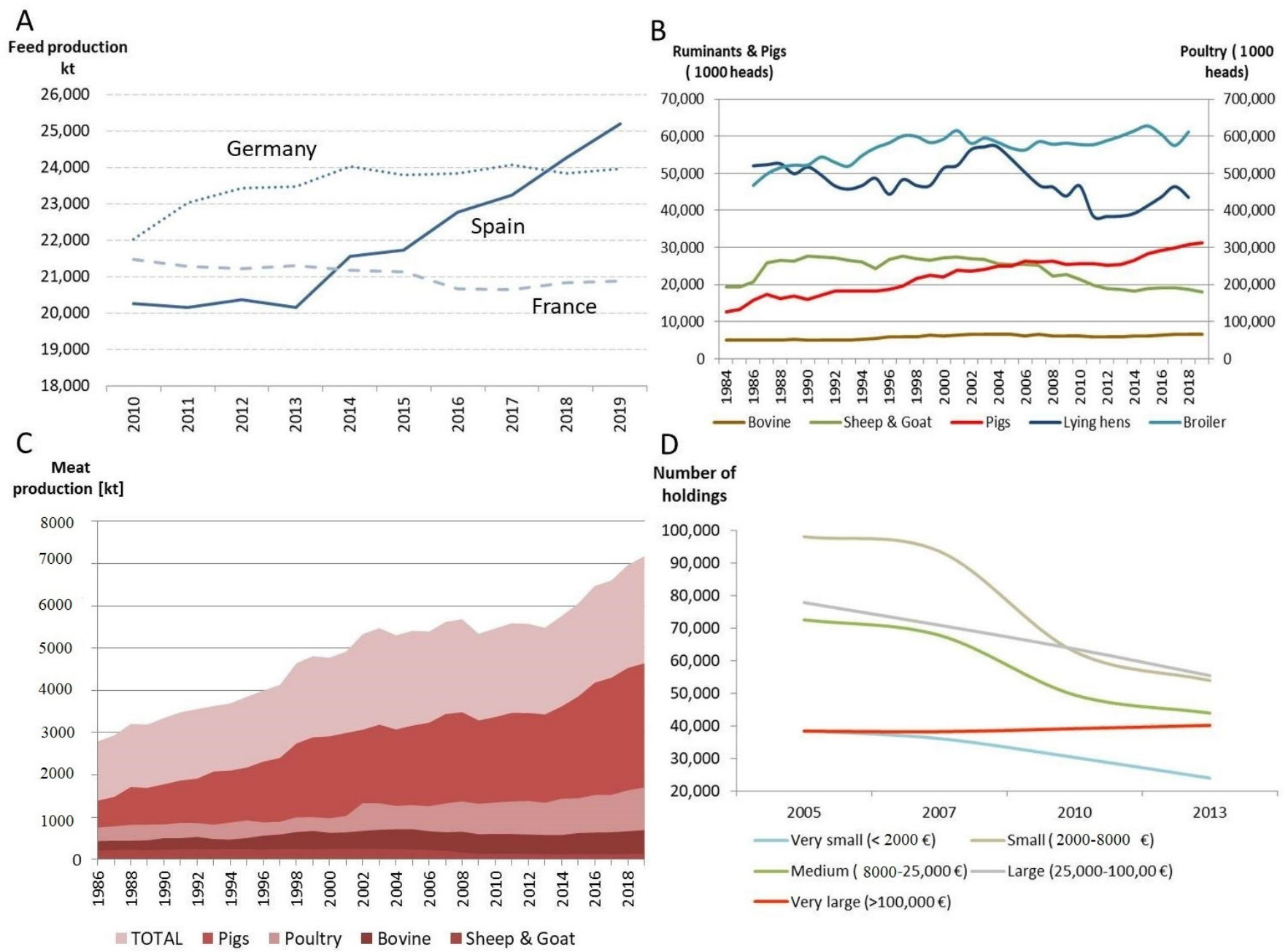

Figure 1. Evolution of: (A) Industrial production of compound feed in major EU producers (2010-2019) [32]; (B) Livestock by species in Spain (1984-2019) [35]; (C) Meat production in Spain by species (1986-2019) [35]; (D) Number of holdings with livestock by economic size of farm (2005-2013) [36]. Data used to create this figure are available in ref. [38].

The process of industrialization of the Spanish agriculture is also characterized by changes in consumption habits that has led to the partial abandoning of the Mediterranean diet in favor of diets richer in animal products $[39,40]$. According to the Soto and colleagues [29], who analyzed the main flows of biomass in Spain for the period 1900-2008, primary productivity has increased by $28 \%$ while Domestic Extraction (DE) has done so by $38 \%$. They also show that the DE of primary crops has grown by $236 \%$ in detriment of the DE of pastures ( $46 \%$ decrease) and forests (17\% decrease). About $40 \mathrm{Mt}, 56 \%$ of the $\mathrm{DE}$, is used for feed, and yet it is not enough to cover the needs of the entire livestock population. As a result, Spain has become a net importer of biomass, going from $773 \mathrm{kt}$ in 1900 to $31,929 \mathrm{kt}$ in 2008, with $42 \%$ going to animal feed [29]. Thus, in recent decades Spain has also followed the so called 'livestock revolution' [12,41], i.e. the shift from plant-based diets to more intensive demand for animal products. The extensive livestock sector has practically disappeared in favor of an agro-industrial production model dependent on the import of raw materials for the manufacture of animal feed. In fact, Spain has become the main producer of animal feed in the euro area.

As widely reported $[9,14,42,43]$, there is a direct connection between the use of one of the main animal feed materials, soya, and the deforestation of valuable ecosystems. On the 
other hand, the reduction in livestock numbers has allowed vegetation to recover in large areas of Spain. Here we compared naturally regenerated areas in Spain during 2000-2010 and those that have been deforested in South America as a result of the use of animal feed in the livestock sector $[44,45]$. We focused on this period because it coincides with the most updated results of the land condition product used by Spain for official reporting to the UN Convention to Combat Desertification [UNCCD, [46]. Our aim is to highlight the transboundary effects of national livestock policies and to illustrate how the success of environmental policies should not be judged merely on domestic achievements, but rather should also consider the environmental impacts it generates in other countries.

\section{Materials and Methods}

The growth of the livestock and its confinement has given rise to two phenomena that run in parallel. On the one hand, the landscape that has stopped being grazed has been recovering in terms of biomass, a dynamic that has been observed in all European Mediterranean countries [30,31,47,48]. On the other hand, the raw materials from which the feed is made require large areas of cultivation. As we have pointed out already, soy has become the key piece of this productive model in Europe [9,14]. To evaluate the effects of the prevailing intensive livestock model, we compared these two phenomena in terms of the area deforested and regenerated.

\subsection{Land Condition Trends Map}

We obtained the land condition trends over time for this study from the 2dRUE results for the period 2000-2010 [46,49]. Although this restricts the scope of our study, it is the most reliable source of information we have for our purpose. This is the official tool used by Spanish National Action Plan against Desertification to report to the UNCCD about the progress in the fight against desertification [50]. Its update for the 2010-2020 decade is still in progress. 2dRUE is a geomatic approach for the assessment and monitoring of land condition focused to detect land degradation within a full range of ecological maturity [51]. It uses archived time-series of a suitable vegetation index and corresponding climate fields and works at spatial and temporal resolutions of $1 \mathrm{~km}$ and 1 month respectively. Land condition states are determined synchronically for the period and whole study area, through implementation of Rain Use Efficiency (i.e. the ratio of Net Primary Productivity to precipitation) at two temporal scales and detecting the position of every location relative to the boundary potentials for its aridity level. In the referred application, land condition states were validated against Soil Organic Carbon. Land condition trends are determined diachronically for each location, by multiple stepwise regressions of the vegetation index (as a proxy to biomass) against time and aridity. Such regressions use annual averages and their validation is statistical. Similarly to other methods (e.g. RESTREND [52]) framed within Sustainable Development Goal 15.3 to achieve Land Degradation Neutrality (LDN) by 2030 [53], 2dRUE considers two main sources of variation at determining vegetation trends: inter-annual oscillations of aridity, and human action, the latter using time as surrogate [54]. Multiple stepwise regression enables finding the specific importance of each predictor if, like in the case of time and aridity, both of them are correlated. Accordingly, $2 \mathrm{dRUE}$ only enables any of these two predictors to be included as a second variable in the regression model if it produces a significant increment of determination. The 2dRUE approach is fully described in del Barrio et al. [51] and has been coded as a free open-source library of functions in R [55].

The intermediate results of the trend analyses consist of respective maps of biomass response over time and biomass response over aridity. The contents of those maps are significant standard regression coefficients. The simplified end-user legend focuses on biomass trends associated to human activities. It consists of four classes: Increasing (biomass accumulation over time whatever the response to aridity variations) $\left(166,075 \mathrm{~km}^{2}\right)$, Degrading (biomass depletion over time whatever the response to aridity variations) (5911 $\mathrm{km}^{2}$ ), Fluctuating (no net biomass change over time, but significant response to aridity 
variations) $\left(141,331 \mathrm{~km}^{2}\right)$ and Static (no response to time neither to changing aridity) $\left(192,175 \mathrm{~km}^{2}\right)$. Whilst Degrading trends involve usually active degradation, it should be noted that Increasing trends may be associated with either ongoing ecological secondary succession (e.g. after abandonment) or with certain types of management (e.g. agricultural intensification).

We targeted the two classes reporting change over time (i.e. Degrading and Increasing) for this study. In addition, we restricted the analysis to potential grazing areas (Table 1), i.e. those where the animals were fed on site with the fodder resources [56] according to the CORINE Land Cover (2006) dataset [57]. The native resolution of $250 \mathrm{~m}$ of this dataset was rescaled to $1000 \mathrm{~m}$ to match that of $2 \mathrm{dRUE}$ by finding the statistical distribution of land cover classes within each target 1000 grid cell, and allocating the modal class to it.

Table 1. Potential CORINE land cover classes [57] suitable for livestock grazing used in this study.

\begin{tabular}{|c|c|c|}
\hline CORINE Land Class & Name & Description \\
\hline 2.3.1 & Pasture & $\begin{array}{l}\text { Permanent grassland characterized by agricultural use or strong human } \\
\text { disturbance. Floral composition dominated by graminacea and influenced by } \\
\text { human activity. Typically used for grazing-pastures, or mechanical harvesting } \\
\text { of grass-meadows. }\end{array}$ \\
\hline 2.4 .4 & Agro-forestry areas & Annual crops or grazing land under the wooded cover of forestry species. \\
\hline 3.1 .1 & Broad-leaved forest & $\begin{array}{l}\text { Vegetation formation composed principally of trees, including shrub and bush } \\
\text { understorey, where broad-leaved species predominate. }\end{array}$ \\
\hline 3.1 .3 & Mixed forest & $\begin{array}{l}\text { Vegetation formation composed principally of trees, including shrub and bush } \\
\text { understorey, where neither broad-leaved nor coniferous species predominate. }\end{array}$ \\
\hline 3.2.1 & Natural grassland & $\begin{array}{l}\text { Grasslands under no or moderate human influence. Low productivity } \\
\text { grasslands. Often situated in areas of rough, uneven ground, steep slopes; } \\
\text { frequently including rocky areas or patches of other (semi-)natural vegetation. }\end{array}$ \\
\hline 3.2 .3 & $\begin{array}{l}\text { Sclerophyllous } \\
\text { vegetation }\end{array}$ & $\begin{array}{l}\text { Bushy sclerophyllous vegetation in a climax stage of development, including } \\
\text { maquis, matorral and garrigue. }\end{array}$ \\
\hline 3.2 .4 & $\begin{array}{c}\text { Transitional } \\
\text { woodland/shrub }\end{array}$ & $\begin{array}{l}\text { Transitional bushy and herbaceous vegetation with occasional scattered trees. } \\
\text { Can represent woodland degradation, forest regeneration / recolonization or } \\
\text { natural succession. }\end{array}$ \\
\hline
\end{tabular}

\subsection{Soy Imports and Land Use Overseas}

This estimation can be done by different procedures and using several databases. Therefore, the assumptions we have used in our study are as follows (the data used and the calculations made can be found in ref. [38]):

(1) We focus on the study of soy because: (a) soy production is directly linked to the deforestation of South American ecosystems, as mentioned above; (b) the soybean area cultivated in Spain is only 1480 ha [58] and is therefore totally dependent on imports; (c) the main use of soybeans in Spain is to manufacture animal feed.

(2) Although land use transformations are occurring worldwide, our analyses are restricted to South America because in this region natural ecosystems are being transformed into farmland to produce soy $[14,45,59]$, while the soybeans from the United States come from a historically agrarian landscape [60].

(3) Our assessment focuses on Brazil, Paraguay and Argentina as they represent more than $99 \%$ of Spain's soy imports from South America [61].

(4) European Compound Feed Manufacturers' Federation (FEFAC) advises members on which sustainability rules to follow when producing or buying feed. However, just $22 \%$ of soya used in Europe was compliant with FEFAC's guidelines. Only $13 \%$ was certified as deforestation-free. In the case of Spain this percentage is zero [62].

(5) Soybean import data by NUTS2 for the decade 2000-2010 [61] are used, which are then aggregated to the national level. Another possibility would have been to use 
feed production data by species, available in national [63] and European [32] statistics. However, and given that our analyses refer to soybean, it would have been necessary to know the percentage of soybean in these feeds, which is not the same for each year or for each species, since the use of this raw material in the manufacture of feeds depends on the protein needs of each species and the price of this raw material.

(6) Spanish soybean imports have been converted into soy field area (ha) by dividing the volume imported from each country $(\mathrm{t})$ by the yield in that country $\left(\mathrm{tha}^{-1}\right)$ in each of the years of the study period [64].

(7) We are assuming that the soybeans imported during this period come from areas that have been deforested or from rangelands [9,14,21-26]. In the latter case, the displaced cattle have forced the creation of new rangelands by occupying forest land. Therefore, in both cases soybean cultivation has implied deforestation.

(8) We assume that soybeans can be grown on the same site for more than ten years. Therefore, the deforested area is not the sum of the cultivated area in each of the eleven years of the series (2000-2010), but the maximum of that series.

(9) We have used information from $[9,14,24,26]$ to situate the ecosystems affected by soybean cultivation.

\section{Results and Discussion}

\subsection{Re-Greening and Deforestation}

Net biomass accumulation over 2000-2010 is found in mountain ranges throughout Spain and in hilly areas of the northwest of the country (Figure 2) [49]. It is often associated with forests and scrublands and rare in agricultural mosaics. Areas showing this trend can be considered as transitional from former extensive grazing to current land abandonment, therefore these are the primary targets of this study. In contrast, biomass depletion trends occur in small clusters that are always associated with limited lifespans of intensive agriculture or, to a lesser extent, afforestations of exotic broadleaved species. Figure 3A shows the balance of Increasing and Degrading trends for each of the CORINE land cover classes considered in this study. As can be seen in this figure, in all categories the surface area that has re-greened is much larger than the areas where biomass has been lost. Overall, the total area in which biomass has accumulated is $7078 \mathrm{kha}$, compared to the $130 \mathrm{kha}$ of 'Decreasing' land condition trend.

The soybean supply for the compound feed industry in Spain for the period 20002010, which amounts to 31,888 kt, comes mainly from South America (68\%; leading Brazil with 59.7\%) and the United States (29.5\%) [61]. The share coming from other South American countries such as Argentina (2.6\%) and Paraguay (4.6\%) are also significant (Figure 3B); it is worth noting that another $1.8 \%$ comes to Spain through third countries of the European Union. The area required to produce all this soybean during the period 2000-2010 can be seen in Figure 3B. As noted above, the estimate of the area of forest and other ecosystems that had to be destroyed for this purpose is not derived from the sum of each year, since soybeans can be grown on the same site for several years. To find out how much area has been used, we have taken the maximum value of the series for each country. These values are 884.32 kha (2005), 164.17 kha (2002) and 140.25 kha (2010), for Brazil, Argentina and Paraguay respectively, for a total of 1188.74 kha.

Intensive livestock farming is not the only feed consumer, although it is the majority. It is important to point out the importance of feed use in extensive livestock farming to supplement their needs in times of fodder shortages. This is one of the main droughtenduring strategies in Spain, once the movement of livestock in search of grazing areas has become a testimonial activity. As we have been able to verify recently [65] the use of supplementary feeding seems to protect these extensive farms against climatic variability and drought, at the cost of transferring degradation to other ecosystems. Although we were unable to track the precise origin of each ton of soybeans, we do know that these fields have directly or indirectly (as livestock is displaced from rangelands to forests or marginal lands) deforested the natural ecosystems of these countries $[14,66,67]$. We can 
assume, with a good deal of certainty [9], that the 915 kha cultivated in Brazil correspond to the destruction of 430 kha of Cerrado, 275 kha of Atlantic forest, 100 kha of Amazon rainforest, and 110 kha of Pampean ecosystems, considering the distribution proposed by several studies $[21,68,69]$. In Paraguay and Argentina, the deforestation to grow soy is concentrated in the Pampa region and the Gran Chaco dry forest $[14,24,26]$.

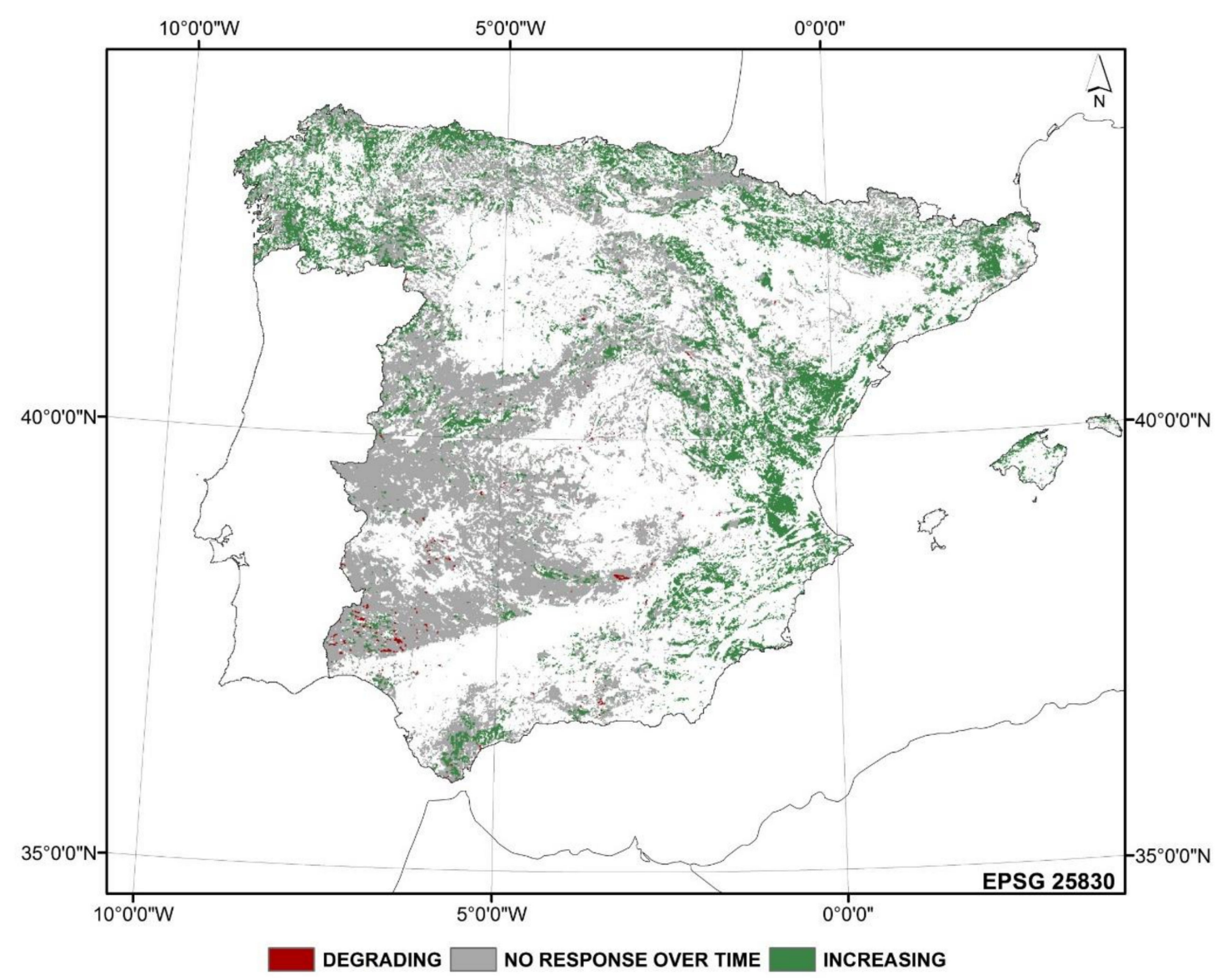

Figure 2. Biomass accumulation ('Increasing', green) or depletion ('Degrading', red) trends over time in mainland and Balearic Spain for the period 2000-2010. In gray the territory that does not show any significant temporal trend during the study period. Derived from Sanjuán et al. (2014) [49]. 
A

CORINE land classes

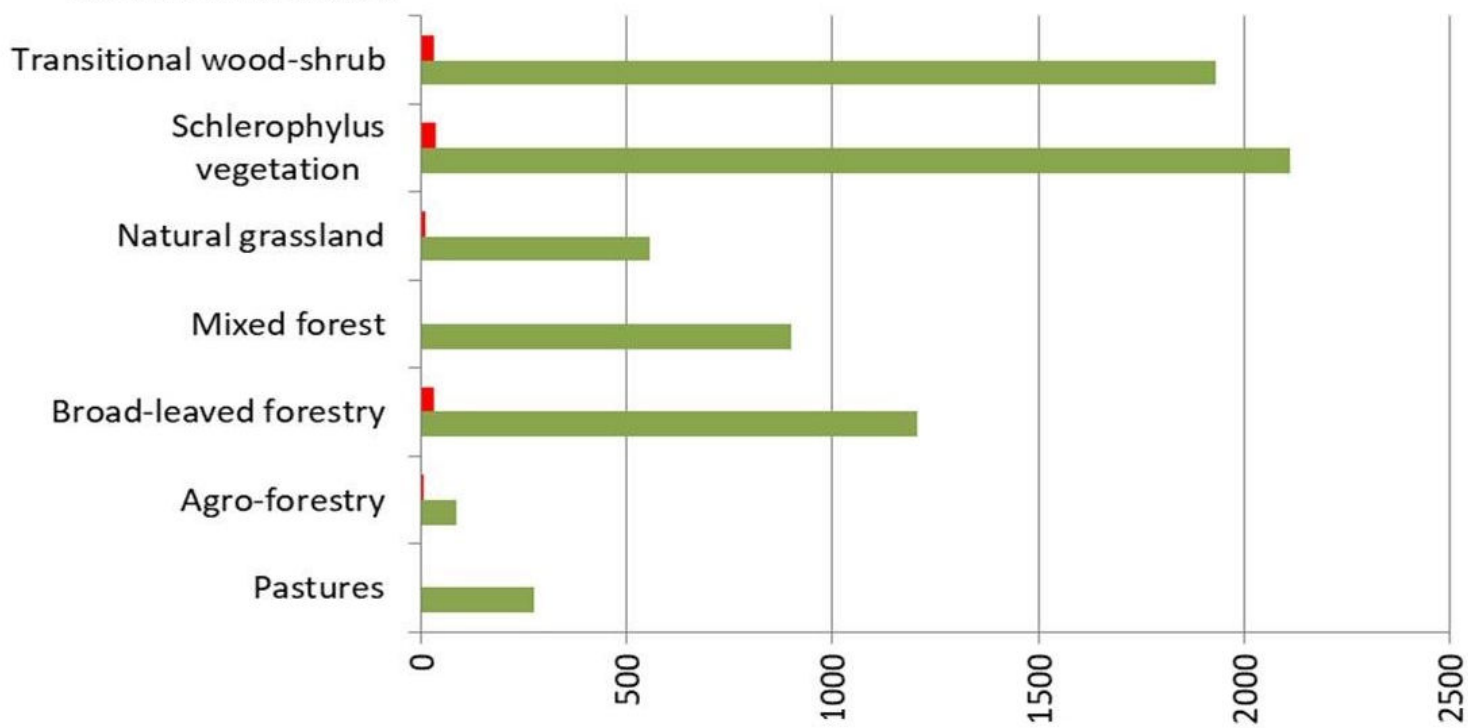

B

kha

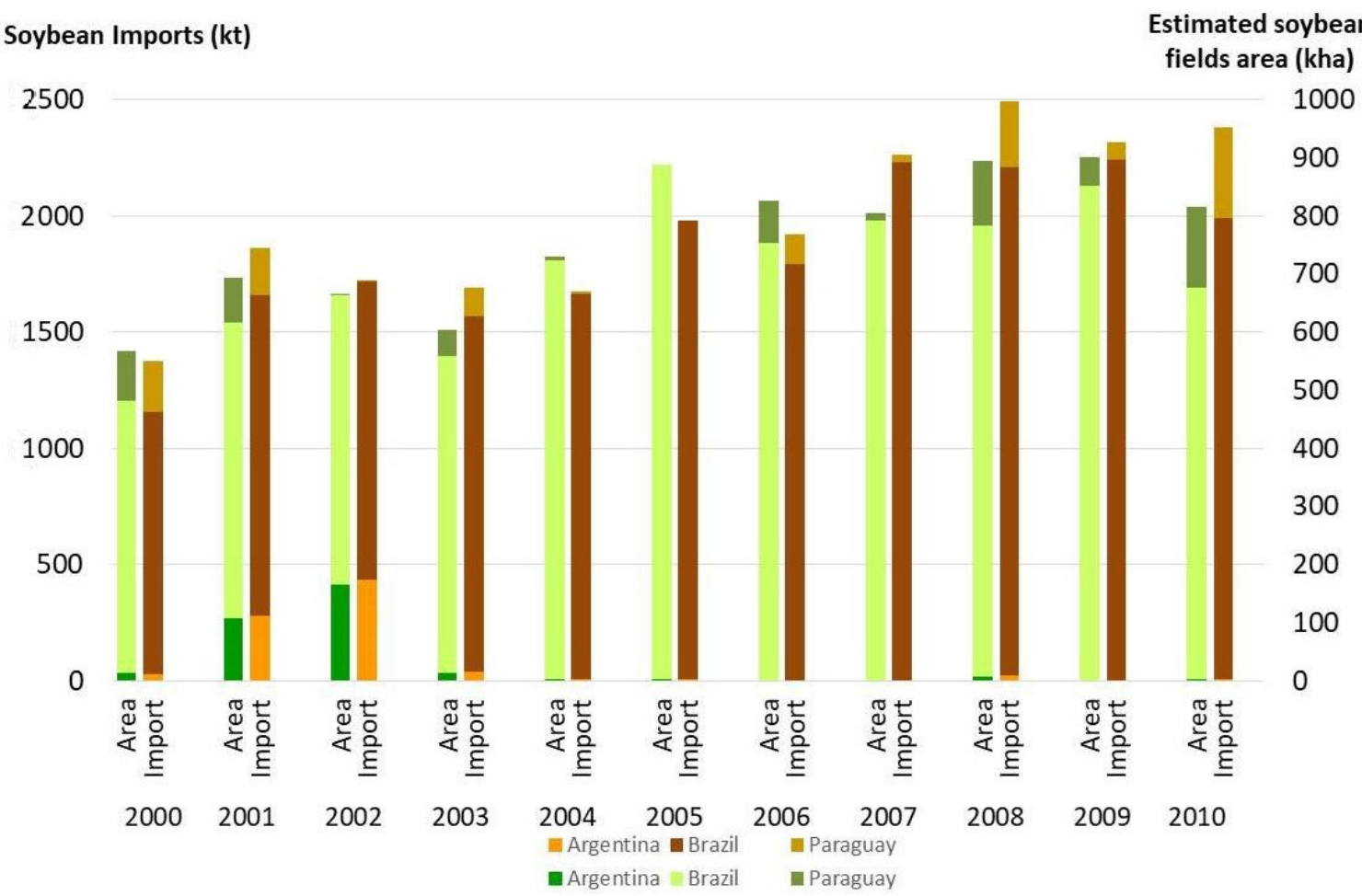

Figure 3. (A) 'Increasing' (green) and 'Degrading' (red) land condition area in Spain for the period 2000-2010 for different CORINE land cover classes [57]; (B) Evolution of the estimated area of soybean fields by country of importation and total imports by country (2000-2010). All of the data used in this paper are available in ref. [38].

\subsection{The Dark Side of Efficiency and Land Degradation Neutrality Paradigm}

The increase of industrial livestock production is justified by its greater efficiency compared to the traditional livestock model based on extensive grazing. The ability to raise a large number of animals in a relatively small space enables larger operations that benefit from technical advances and economies of scale [70], improving productivity and resource use efficiency per livestock unit [8]. The booming production of monogastric 
animals, such as chickens and pigs, is facilitated by the fact that these species metabolize concentrated feed more efficiently than cattle (or sheep) [59] and by their short life cycles, which accelerate genetic improvements [15]. In Spain, carcass weights increased by about $99 \%$ for chicken and $92 \%$ for beef cattle from the early 1960s to 2019 , but surprisingly decreased by about $2 \%$ for pigs [64]. Likewise, increases in milk production per animal and egg production per chicken have increased by up to $352 \%$ and $130 \%$ respectively over the same time period [64]. Conversion rates of feed to meat are another indicator showing the high efficiency of the intensive production system. The United States Department of Agriculture [71] reported that it takes up to $2.6 \mathrm{~kg}$ of feed to produce $1 \mathrm{~kg}$ of chicken meat, $6.5 \mathrm{~kg}$ of feed to produce $1 \mathrm{~kg}$ of pig meat and $7 \mathrm{~kg}$ of feed to produce $1 \mathrm{~kg}$ of beef. The conversion rates for Spain are, respectively, 1.8 [72], 3-3.2 [73] and 4.3-4.5 [74], considerably more efficient.

The current specialized livestock breeds oriented to produce meat and milk depend on high-quality processed feed, require a lot of care (controlled environments, medication) and only convert $10-30 \%$ of their feed intake into edible products [75,76]. An alternative set of conversion indicators can be used to show aspects that do not take conventional ratios into account. For example, if not including material that is not normally eaten, such as bone, then producing $1 \mathrm{~kg}$ of edible meat in the U.S. by industrial methods requires 20, 7.3 and $4.5 \mathrm{~kg}$ of feed for beef, pig and chicken, respectively [77]. The balance is also not very favorable if calorie and protein conversion rates are used: For every 100 calories of grain fed to animals, we get only about 40 new calories of milk, 22 calories of eggs, 12 of chicken, 10 of pork, or 3 of beef. Similarly, for every 100 grams of grain protein that we feed to animals, we get only about 43 new grams of protein in milk, 35 in eggs, 40 in chicken, 10 in pork, or 5 in beef [12].

It might be tempting to extrapolate the discourse of efficiency to compare the areas regenerated by the abandonment of livestock with deforestation resulting from the production of compound feed. Our data [38] show 7077.8 kha for the former, and 1188.7 kha for the latter within 2000-2010. A shallow conclusion would be that land regeneration in Spain largely offsets land degradation overseas. Moreover, it could be also argued that lands in tropical regions are more productive than Mediterranean rangelands, and that the excess degradation shown by these figures accounts in reality for the increase in meat consumption. However, this would be fallacious and against the founding principles of the LDN paradigm promoted by the UNCCD [78,79] and of the UN Sustainable Development Goal 15.3 [80]. First, because by shifting land degradation to another country, any neutralization must be considered at a higher aggregation level. This goes against any equity principle. Second, when comparing reforestation/deforestation balances at the global level [81] the compensation mechanism foreseen by LDN runs the risk of being misinterpreted as a license to degrade, even though the UN explicitly denies this possibility [79]. The scientific conceptual framework for LDN explicitly advises to 'ensure at the national level a neutral balance between degraded and not degraded land' [82] and to implement it within unique land types [83]. And third, in the case at hand, it is not possible to speak of compensation when comparing the destruction of well-structured ecosystems, such as primary South American forests, with the accumulation of biomass in anthropized landscapes that have been abandoned in a disorderly manner. In addition, agricultural yields in tropical fields that have been deforested are low compared to their temperate zone counterparts [19].

Although at first glance the technification of livestock farming can be considered as a new achievement of human domination of Earth's ecosystems [84], the fact is that it is a highly inefficient production model. Estimates by the UN Environmental Programme show that a $\mathrm{kg}$ of cereals provides six times as many calories if eaten directly by people than if it is used to feed livestock [76], i.e. 83\% of those calories are invested in maintaining the metabolism of the confined animals. Native breeds that have been perfectly adapted for centuries or millennia to producing food in harsh environments and exploiting resources that cannot be used otherwise (e.g. harvest residues) have been lost. The territory historically allocated to livestock was rangelands, lands discarded for cultivation 
where herbivores were able to use to transform grass/shrubs and agricultural residues into high-quality protein. The productivity of the agroindustrial model is based on using artificial inputs (chemical fertilizers use has increased in Spain from 0.5 to $51.2 \mathrm{~kg} / \mathrm{ha}$ of N and from 1.2 to $21.8 \mathrm{~kg} / \mathrm{ha}$ of $\mathrm{P}_{2} \mathrm{O}_{5}$ between 1900 and 2008 [29]) and generating negative externalities that are not usually included in the calculation of livestock efficiency.

\subsection{Creating More Vulnerable Landscapes: Wildfires and Monocultures}

The lack of grazing and maintenance of natural vegetation cover has led in many Mediterranean countries to a process of secondary succession, in which the slopes are initially colonized by shrubs and later by forests [85-87]. This has created enormous extensions of homogeneous ligneous vegetation masses with increased fuel loads and without discontinuities [88], giving rise to fire-prone landscapes [89]. As a result of this risk, the National Action Program against Desertification considers abandoned lands as one of the five scenarios of desertification in Spain [50,90]. This is a peculiar scenario, since desertification is usually related to the overexploitation of resources. However, the abandonment of croplands and grazing lands in ecosystems adapted to human intervention are behind erosion problems and the increased risk of wildfires. Although low intensity and low frequency fires have always occurred naturally and play a regulatory role in Mediterranean ecosystems (against phytotoxic agents, promoting seed germination, etc.) [91], when their virulence and recurrence increase (median fire return has been reduced from $\sim 30$ to $\sim 10$ years in some areas [92]) they cause serious damage by exposing the soil to heavy rainfall, preventing seeders from replenishing seed banks [93], depleting resprouters bud banks [94], and/or favoring invasive species [95].

The speed and intensity of the regeneration of natural vegetation in Spain over the last decades because of land abandonment has triggered the incidence of forest fires $[87,96]$. Although for the period 2010-2020 the average area affected by forest fires decreased by $27 \%$ compared to the previous decade [97], the proportion of megafires (a burned surface area greater than 500 ha of forest) is growing year by year $[97,98]$. Global warming, which is being particularly acute in the Mediterranean Basin [99,100], announces that this is a problem that will increase and that we must expect higher fire risk, longer fire seasons and more frequent large, severe fires [101-103]. Although megafires only represent $0.18 \%$ of the total number of fires, they account for $40 \%$ of the area burned [97]. This type of wildfire is born from the abandonment of traditional rural activities that maintained a landscape mosaic that provided sufficient fuel fragmentation [104,105]. The fire, finding no obstacles in its path and spurred by drier conditions due to climate change [91,106], creates enormous fronts that are very difficult to combat with the usual means of extinction. One of the most promising solutions to combat megafires is, ironically, to bring back extensive livestock to create a grazed fuelbreak network $[86,87,105]$.

It is worth to mention that not all of the biomass accumulated has been in potentially grazable land uses. Re-greening has also occurred in abandoned agricultural lands and in forests that have increased their biomass. In total, this natural reforestation has occurred in 16,600 kha [49], and therefore the uses studied represent $42 \%$ of the total of this territory in which the land condition has increased.

If in the Mediterranean one of the consequences of the current livestock model is the creation of more flammable landscapes, soybean monocultures have taken over large areas across South America. In fact, of the 24 Mha that were cultivated in South America between 2000 and 2010, the production of soybean fields occupies 20 Mha [14]. This agricultural model has been driven by the international demand for soy. The result of replacing natural ecosystems with annual monocultures is the production of an artificial ecosystem requiring constant human intervention that mostly benefits a few large producers [107]. The increase in production costs forced by this type of agriculture can only be overcome by large-scale production that lowers the cost per unit. Then, as price falls and costs goes up (as in USA [27] or in the European Union [108]), small holders are excluded from the agricultural market and their only option is to become employees or franchisees of 
large agricultural companies. This self-reinforcement mechanism, known as Agricultural Treadmill, was already described in the 1950s [109] and the result is that agriculture is left in fewer hands $[27,110]$.

\section{Conclusions}

We have explored how the changes in the way livestock is farmed that have taken place in Spain over the last decades have affected its land during the period 2000-2010. On the one hand, we have estimated that 7078 kha have improved their condition after the abandonment of grazed areas and the subsequent process of secondary succession. On the other hand, we have estimated that 1188 kha of the Amazon rainforest, Gran Chaco dry forest and other valuable ecosystems have disappeared to make room for soy fields producing feed used by Spanish livestock. Although these figures are not negligible, we must bear in mind that Spain only represents $2.23 \%$ of the total value of international soybean imports, while China alone accounts for 57\% [111].

Although in a first and simplistic interpretation it seems that the current agro-livestock model can be considered as a net gain in biomass, the truth is that, far from reducing the impact on the environment, there are global (destruction of primary forests) and local (increase of megafires) repercussions that should not be hidden under this increase in forest biomass. It must be emphasized that this type of compensation does not fall under the LDN initiative, which explicitly warns that neutrality must be achieved at the country level and within similar land cover types. Moreover, the increase in biomass or plant cover per se cannot be considered as a success of environmental policies. Proof of this is that the increase in megafires being observed is due in part to the accumulation of firewood and the creation of homogeneous forest masses because of the abandonment of extensive livestock grazing.

In this globalization era, integrated planning is needed more than ever, so that the potential negative externalities of a new land use model can be foreseen and deactivated (or at least minimized). Our results show that restricting ourselves to political borders makes little sense when assessing the impacts of livestock farming on land, and that actions to manage a territory must be cross-sectoral, since the success of one action can mean the complete failure of others.

Author Contributions: Conceptualization, J.M.-V.; Formal analysis, J.M.-V., M.E.S. and G.d.B.; Investigation, F.T.M.; Methodology, J.M.-V., M.E.S., G.d.B. and A.R.; Project administration, F.T.M.; Resources, F.T.M.; Software, M.E.S. and A.R.; Supervision, J.M.-V., G.d.B. and F.T.M.; Validation, M.E.S.; Visualization, M.E.S., E.G. and A.R.; Writing-original draft, J.M.-V.; Writing-review \& editing, J.M.-V., M.E.S., G.d.B., E.G. and F.T.M. All authors have read and agreed to the published version of the manuscript.

Funding: This study was funded by the European Research Council grant agreement $\mathrm{n}^{\circ} 647038$ (BIODESERT). FTM acknowledges support from Generalitat Valenciana (CIDEGENT/2018/041).

Data Availability Statement: The data presented in this study are openly available in FigShare at https:/ / doi.org/10.6084/m9.figshare.13134977.v1.

Conflicts of Interest: The authors declare no conflict of interest.

\section{References}

1. Buchan, N.R.; Grimalda, G.; Wilson, R.; Brewer, M.; Fatas, E.; Foddy, M. Globalization and human cooperation. Proc. Natl. Acad. Sci. USA 2009, 106, 4138-4142. [CrossRef] [PubMed]

2. Steffen, W.; Broadgate, W.; Deutsch, L.; Gaffney, O.; Ludwig, C. The trajectory of the Anthropocene: The Great Acceleration. Anthr. Rev. 2015, 2, 81-98. [CrossRef]

3. Cherlet, M.; Hutchinson, C.; Reynolds, J.; Hill, J.; Sommer, S.; von Maltitz, G. World Atlas of Desertification; Cherlet, M., Hutchinson, C., Reynolds, J., Hill, J., Sommer, S., von Maltitz, G., Eds.; Publication Office of the European Union: Luxembourg, 2018; ISBN 978-92-79-75350-3.

4. Yu, Y.; Feng, K.; Hubacek, K. Tele-connecting local consumption to global land use. Glob. Environ. Chang. 2013, 23, 1178-1186. [CrossRef] 
5. Nyström, M.; Jouffray, J.B.; Norström, A.V.; Crona, B.; Søgaard Jørgensen, P.; Carpenter, S.R.; Bodin Galaz, V.; Folke, C. Anatomy and resilience of the global production ecosystem. Nature 2019, 575, 98-108. [CrossRef]

6. Fuchs, R.; Brown, C.; Rounsevell, M. Europe's Green Deal offshores environmental damage to other nations. Nature 2020, 586, 671-673. [CrossRef] [PubMed]

7. Alexandratos, N.; Bruinsma, J.F. World Agriculture Towards 2030/2015: The 2012 Revision; Agricultural Development Economics Division Food and Agriculture Organization of the United Nations: Rome, Italy, 2012. [CrossRef]

8. Bai, Z.; Ma, W.; Ma, L.; Velthof, G.L.; Wei, Z.; Havlík, P.; Oenema, O.; Lee, M.R.F.; Zhang, F. China's livestock transition: Driving forces, impacts, and consequences. Sci. Adv. 2018, 4, 1-12. [CrossRef] [PubMed]

9. Boerema, A.; Peeters, A.; Swolfs, S.; Vandevenne, F. Soybean Trade: Balancing Environmental and Socio-Economic Impacts of an Intercontinental Market. PLoS ONE 2016, 11, e0155222. [CrossRef]

10. D'Odorico, P.; Bhattachan, A.; Davis, K.; Ravi, S.; Runyan, C. Global desertification: Drivers and feedbacks. Adv. Water Resour. 2013, 51, 326-344. [CrossRef]

11. European Commission EU Market: Cereals Supply \& Demand. Available online: http://ec.europa.eu/agriculture/cereals / balance-sheets / cereals/overview_en.pdf (accessed on 21 April 2020).

12. Cassidy, E.S.; West, P.C.; Gerber, J.S.; Foley, J.A. Redefining agricultural yields: From tonnes to people nourished per hectare. Environ. Res. Lett. 2013, 8, 034015. [CrossRef]

13. Wang, J.; Liu, Q.; Hou, Y.; Qin, W.; Lesschen, J.P.; Zhang, F.; Oenema, O. International trade of animal feed: Its relationships with livestock density and N and P balances at country level. Nutr. Cycl. Agroecosystems 2018, 110, 197-211. [CrossRef]

14. WWF (World Wildlife Fund). The Growth of Soy: Impacts and Solutions; WWF: Gland, Switzerland, 2014.

15. Naylor, R.; Steinfeld, H.; Falcon, W.; Galloway, J.; Smil, V.; Bradford, E.; Alder, J.; Mooney, H. Losing the links between livestock and land. Science 2005, 310, 1621-1622. [CrossRef]

16. González-Bernal, M.J.; Rubiales, D. Las leguminosas grano en la agricultura española y europea. Arbor 2016, 192, a311. [CrossRef]

17. Godfray, H.C.; Beddington, J.R.; Crute, I.R.; Haddad, L.; Lawrence, D.; Muir, J.F.; Pretty, J.; Robinson, S.; Thomas, S.M.; Toulmin, C. Food security: The challenge of the present. Sicence 2010, 327, 812-818. [CrossRef]

18. West, P.C.; Gerber, J.S.; Engstrom, P.M.; Mueller, N.D.; Brauman, K.A.; Carlson, K.M.; Cassidy, E.S.; Johnston, M.; MacDonald, G.K.; Ray, D.K.; et al. Leverage points for improving global food security and the environment. Science 2014, 345, 325-328. [CrossRef] [PubMed]

19. Foley, J.A.; Ramankutty, N.; Brauman, K.A.; Cassidy, E.S.; Gerber, J.S.; Johnston, M.; Mueller, N.D.; O'Connell, C.; Ray, D.K.; West, P.C.; et al. Solutions for a cultivated planet. Nature 2011, 478, 337-342. [CrossRef]

20. De Visser, C.L.M.; Schreuder, R.; Stoddard, F. The EU's dependency on soya bean import for the animal feed industry and potential for EU produced alternatives. OCL 2014, 21, 1-8. [CrossRef]

21. Smaling, E.M.A.; Roscoe, R.; Lesschen, J.P.; Bouwman, A.F.; Comunello, E. From forest to waste: Assessment of the Brazilian soybean chain, using nitrogen as a marker. Agric. Ecosyst. Environ. 2008, 128, 185-197. [CrossRef]

22. Olsen, N.; Bishop, J. The Financial Costs of REDD: Evidence from Brazil and Indonesia; IUCN: Gland, Switzerland, 2009.

23. Lathuillière, M.J.; Johnson, M.S.; Galford, G.L.; Couto, E.G. Environmental footprints show China and Europe's evolving resource appropriation for soybean production in Mato Grosso, Brazil. Environ. Res. Lett. 2014, 9, 074001. [CrossRef]

24. Vallejos, M.; Volante, J.N.; Mosciaro, M.J.; Vale, L.M.; Bustamante, M.L.; Paruelo, J.M. Transformation dynamics of the natural cover in the Dry Chaco ecoregion: A plot level geo-database from 1976 to 2012. J. Arid Environ. 2015, 123, 3-11. [CrossRef]

25. World Resource Institute Gobal Forest Watch. Available online: https:/ / www.globalforestwatch.org/ (accessed on 2 June 2020).

26. Baumann, M.; Israel, C.; Piquer-Rodríguez, M.; Gavier-Pizarro, G.; Volante, J.N.; Kuemmerle, T. Deforestation and cattle expansion in the Paraguayan Chaco 1987-2012. Reg. Environ. Chang. 2017, 17, 1179-1191. [CrossRef]

27. Crews, T.E.; Carton, W.; Olsson, L. Is the future of agriculture perennial? Imperatives and opportunities to reinvent agriculture by shifting from annual monocultures to perennial polycultures. Glob. Sustain. 2018, 1. [CrossRef]

28. Emanuelli, M.S.; Jonsen, J.; Monsalve Suarez, S. Red Sugar, Green Deserts; FIAN International, FIAN Sweden: Stockholm, Sweden, 2009; ISBN 9789197718837. Available online: https://www.researchgate.net/profile/Alberto_Alonso-Fradejas/publication/ 308778884_The_human_right_to_food_versus_the_new_colonizers_of_agriculture_in_Guatemala_Sugarcane_and_african_ palm/links/57efc15708ae886b89753070/The-human-right-to-food-versus-the-new-colonizers-of-agriculture-in-GuatemalaSugarcane-and-african-palm.pdf (accessed on 6 September 2020).

29. Soto, D.; Infante-Amate, J.; Guzmán, G.I.; Cid, A.; Aguilera, E.; García, R.; González de Molina, M. The social metabolism of biomass in Spain, 1900-2008: From food to feed-oriented changes in the agro-ecosystems. Ecol. Econ. 2016, 128, 130-138. [CrossRef]

30. Hill, J.; Stellmes, M.; Udelhoven, T.; Röder, A.; Sommer, S. Mediterranean desertification and land degradation: Mapping related land use change syndromes based on satellite observations. Glob. Planet. Change 2008, 64, 146-157. [CrossRef]

31. Puigdefábregas, J.; Mendizabal, T. Perspectives on desertification: Western Mediterranean. J. Arid Environ. 1998, 39, 209-224. [CrossRef]

32. European Feed Manufacturers' Federation (FEFAC). Compound Feed Production (1989-2019); FEFAC: Brussels, Belgium, 2018.

33. García-Dory, M.A.; Martinez Vicente, S. La ganadería en España; Alianza Editorial: Madrid, Spain, 1988.

34. Pardo Abad, C.J. Problemática de la ganadería extensiva en España. Estud. Geogr. 1996, 57, 125-149. [CrossRef] 
35. European Commission Eurostat. Animal Production. Available online: https://ec.europa.eu/eurostat/web/agriculture/data/ database?p_p_id=NavTreeportletprod_WAR_NavTreeportletprod_INSTANCE_ff6j1D0oti4U\&\&p_p_lifecycle=0\&p_p_state= normal\&p_p_mode=view\&p_p_col_id=column-2\&p_p_col_count=1 (accessed on 7 September 2020).

36. European Commission Eurostat. Agriculture. Farm Structure. Available online: https://appsso.eurostat.ec.europa.eu/nui/show. do?dataset=ef_olsaareg\&lang=en (accessed on 6 September 2020).

37. Greenpeace. Alimentando el Problema. La Peligrosa Intensificación de la Ganadería en Europa; Greenpeace: Madrid, Spain, 2019.

38. Martínez-Valderrama, J.; Sanjuán, M.E.; del Barrio, G.; Guirado, E.; Ruiz, A.; Maestre, F.T. Data on the Re-Greening of Spain's Landscape at the Expense of South American Agricultural Expansion. 2020. Available online: https://doi.org/10.6084/m9 .figshare.13134977.v1 (accessed on 15 February 2021).

39. González de Molina, M.; Soto Fernández, D.; Guzmán Casado, G.; Infante-Amate, J.; Aguilera Fernández, E.; Vila Traver, J.; García Ruiz, R. Environmental Impacts of Spanish Agriculture's Industrialization. In The Social Metabolism of Spanish Agriculture, 1900-2008: The Mediterranean Way Towards Industrialization; González de Molina, M., Soto Fernández, D., Guzmán Casado, G., Infante-Amate, J., Aguilera Fernández, E., Vila Traver, J., García Ruiz, R., Eds.; Springer International Publishing: Cham, Switzerland, 2020; ISBN 978-3-030-20900-1.

40. Blas, A.; Garrido, A.; Unver, O.; Willaarts, B. A comparison of the Mediterranean diet and current food consumption patterns in Spain from a nutritional and water perspective. Sci. Total Environ. 2019, 664, 1020-1029. [CrossRef]

41. Delgado, C.; Rosegrant, M.W.; Steinfeld, H.; Ehui, S.; Courbois, C. The Coming Livestock Revolution; Background Paper n. 6; International Food Policy Research Institute. FAO: Rome, Italy, 1999.

42. Livestock in a Changing Landscape. Vol 1. Drivers, Consequences, and Responses; Steinfeld, H., Mooney, H.A., Schneider, F., Neville, L.E. (Eds.) Island Press: Washington, DC, USA, 2013.

43. Greenpeace. Enganchados a la Carne; Greenpeace: Madrid, Spain, 2019.

44. Lassaletta, L.; Billen, G.; Romero, E.; Garnier, J.; Aguilera, E. How changes in diet and trade patterns have shaped the N cycle at the national scale: Spain (1961-2009). Reg. Environ. Chang. 2014, 14, 785-797. [CrossRef]

45. Karstensen, J.; Peters, G.; Andrew, R. Attribution of $\mathrm{CO}_{2}$ emissions from Brazilian deforestation to consumers between 1990 and 2010. Environ. Res. Lett. 2013, 8. [CrossRef]

46. Del Barrio, G.; Sanjuán, M.E.; Ruiz, A.; Martínez-Valderrama, J.; Puigdefábregas, J. Case study: Land condition surveillance using geospatial data (Iberian Peninsula and Maghreb). In World Atlas of Desertification; Cherlet, M., Hutchinson, C., Reynolds, J., Hill, J., Sommer, S., von Maltitz, G., Eds.; Publication Office of the European Union: Luxembourg, 2018; ISBN 978-92-79-75350-3.

47. MacDonald, D.; Crabtree, J.R.; Wiesinger, G.; Dax, T.; Stamou, N.; Fleury, P.; Gutierrez Lazpita, J.; Gibon, A. Agricultural abandonment in mountain areas of Europe: Environmental consequences and policy response. J. Environ. Manage. 2000, 59, 47-69. [CrossRef]

48. Taillefumier, F.; Piégay, H. Contemporary land use changes in Prealpine Mediterranean mountains: A multivariate GIS-based approach applied to two municipalities in the Southern French Prealps. Catena 2013, 267-296. [CrossRef]

49. Sanjuán, M.E.; del Barrio, G.; Ruiz, A.; Rojo, L.; Puigdefábregas, J.; Martínez, A. Evaluación y Seguimiento de la Desertificación en España: Mapa de la Condición de la Tierra 2000-2010; Ministerio de Agricultura, Alimentación y Medio Ambiente (España): Madrid, Spain, 2014; ISBN 978-84-491-1395-6.

50. Ministerio de Agricultura y Medio Ambiente. Programa de Acción Nacional Contra la Desertificación; Ministerio de Agricultura y Medio Ambiente: Madrid, Spain, 2008.

51. Del Barrio, G.; Puigdefabregas, J.; Sanjuan, M.E.; Stellmes, M.; Ruiz, A. Assessment and monitoring of land condition in the Iberian Peninsula, 1989-2000. Remote Sens. Environ. 2010, 114, 1817-1832. [CrossRef]

52. Wessels, K.J.; Prince, S.D.; Malherbe, J.; Small, J.; Frost, P.E.; VanZyl, D. Can human-induced land degradation be distinguished from the effects of rainfall variability? A case study in South Africa. J. Arid Environ. 2007, 68, 271-297. [CrossRef]

53. Orr, B.J.; Cowie, A.L.; Castillo Sanchez, V.M.; Chasek, P.; Crossman, N.D.; Erlewein, A.; Louwagie, G.; Maron, A.; Erlewein, M.; Metternicht, G.I.; et al. Scientific conceptual framework for land degradation neutrality. In A Report of the Science-Policy Interface; United Nations Convention to Combat Desertification (UNCCD): Bonn, Germany, 2017.

54. Evans, J.; Geerken, R. Discrimination between climate and human-induced dryland degradation. J. Arid Environ. 2004, 57, 535-554. [CrossRef]

55. Ruiz, A.; Sanjuan, M.E.; del Barrio, G.; Puigdefabregas, J. r2dRue: $2 d$ Rain Use Efficience Library. R Package Version 1.04. Comprehensive R Archive Network. 2011. Available online: https:/ / cran.r-project.org/web/packages/r2dRue/r2dRue.pdf (accessed on 22 April 2020).

56. Rodríguez, M.; Luque, R.; Hervás, C.; Moreno, C.; Gaona, C.; Rodríguez-Estévez, V. Estudio de los Pastos en Andalucía y Castilla-La Mancha y su Aprovechamiento Racional con Ganado Ecológico; Junta de Andalucía: Sevilla, Spain, 2014; ISBN 978-84-606-5836-8.

57. European Environment Agency (EEA). Corine Land Cover 2006 (CLC2006) Seamless Vector Database. Available online: https: / / land.copernicus.eu/pan-european/corine-land-cover/clc-2006 (accessed on 16 April 2020).

58. Ministerio de Agricultura Pesca y Alimentación. Anuario de Estadística 2019. Available online: https://www.mapa.gob.es/ estadistica/pags/anuario/2019/CAPITULOSPDF/CAPITULO07/pdfc07_4.11.1.pdf (accessed on 1 February 2021).

59. Steinfeld, H.; Gerber, P.; Wassenaar, T.; Castel, V.; Rosales, M.; Haan, C. Livestock's long shadow. Environmental Issues and Options; FAO: Rome, Italy, 2006; Volume 5. 
60. American Soybean Association. Soystats. A Reference Guide to Important Soybean Facts and Figures. Available online: http:/ / soystats.com/ (accessed on 16 December 2020).

61. Instituto de Comercio Exterior (ICEX) Estadísticas Españolas de Comercio Español (ESTACOM). Available online: https:/ wwww. icex.es/icex/es/navegacion-principal/todos-nuestros-servicios/informacion-de-mercados/estadisticas/index.html (accessed on 7 September 2020).

62. Kuepper, B.; Riemersma, M. European Soy Monitor; IDH, IUCN NL \& Profundo: Amsterdam, The Netherlands, 2019.

63. Ministerio de Agricultura Pesca y Alimentación. Producción de Piensos y Comercio Exterior. Available online: https://www. mapa.gob.es/es/ganaderia/temas/alimentacion-animal/acceso-publico/produccion_de_piensos_y_comercio_exterior.aspx (accessed on 29 January 2021).

64. FAO (Food and Agriculture Organization of the United Nations). FAOSTAT Statistical Database. Available online: fao.org/ faostat/en/ (accessed on 25 October 2019).

65. Martínez-Valderrama, J.; Ibáñez, J.; Ibáñez, M.A.; Alcalá, F.J.; Sanjuán, M.E.; Ruiz, A.; del Barrio, G. Assessing the sensitivity of a Mediterranean commercial rangeland to droughts under climate change scenarios by means of a multidisciplinary integrated model. Agric. Syst. 2021, 187, 103021. [CrossRef]

66. Arima, E.; Richards, P.; Walker, R.; Caldas, M. Statistical confirmation of indirect land use change in the Brazilian Amazon. Environ. Res. Lett. 2011, 6, 024010. [CrossRef]

67. Lapola, D.M.; Schaldach, R.; Alcamo, J.; Bondeau, A.; Koch, J.; Koelking, C.; Priess, J.A. Indirect land-use changes can overcome carbon savings from biofuels in Brazil. Proc. Natl. Acad. Sci. USA 2010, 107, 3388-3393. [CrossRef]

68. Macedo, M.N.; DeFries, R.S.; Morton, D.C.; Stickler, C.M.; Galford, G.L.; Shimabukuro, Y.E. Decoupling of deforestation and soy production in the southern Amazon during the late 2000s. Proc. Natl. Acad. Sci. USA 2012, 109, 1341-1346. [CrossRef]

69. Hecht, S. Soybeans, Development and Conservation on the Amazon Frontier. Dev. Chang. 2005, 36, 375-404. [CrossRef]

70. Stevenson, P.J. Industrial Livestock Production: The Twin Myths of Efficiency and Necessity; Compassion in World Farming: Surrey, UK, 2015.

71. Trostle, R. Global Agricultural Supply and Demand: Factors Contributing to the Recent Increase in Food Commodity Prices; Diane Publishing: Collingdale, PA, USA, 2010.

72. Garcés Navarro, C. Aves de Carne. Bases Zootécnicas para el Cálculo del Balance Alimentario de Nitrógeno y de Fósforo; Ministerio de Agricultura y Pesca, Alimentación y Medio Ambiente: Madrid, Spain, 2017.

73. Tejedor, J.M. Economía en la explotación porcina. Ganadería 2006, 43, 26-30.

74. Alberti, P.; Lahoz, F.; Sañudo, C.; Olleta, J.L. Chequeo al bovino español. Surcos de Aragón 1999, 61, $24-27$.

75. Westhoek, H.; Rood, T.; van den Berg, M.; Janse, J.; Nijdam, D.; Reudink, M.; Stehfest, E. The Protein Puzzle. The Consumption and Production of Meat, Dairy and Fish in the European Union; PBL Netherlands Environmental Assessment Agency: The Hague, The Netherlands, 2011.

76. UNEP (United Nations Environmental Programme). The Environmental Food Crisis—The Environment's Role in Averting Future Food Crises; Nelleman, C., Macdevette, M., Manders, T., Eickhout, B., Svihus, B., Gerdien Prins, A., Kaltenborn, B.P., Eds.; UNEP (United Nations Environmental Programme): Nairobi, Kenya, 2009; ISBN 978-82-7701-054-0.

77. Smil, V. Feeding the World: A Challenge for the Twenty-First Century; The MIT Press: Cambridge, MA, USA, 2000.

78. Cowie, A.L.; Orr, B.J.; Castillo Sanchez, V.M.; Chasek, P.; Crossman, N.D.; Erlewein, A.; Louwagie, G.; Maron, M.; Metternicht, G.I.; Minelli, S.; et al. Land in balance: The scientific conceptual framework for Land Degradation Neutrality. Environ. Sci. Policy 2018, 79, 25-35. [CrossRef]

79. Safriel, U. Land degradation neutrality (LDN) in drylands and beyond - where has it come from and where does it go. Silva Fenn. 2017, 51, 1-19. [CrossRef]

80. United Nations. United Nations Working Group on the Issue of Human Rights and Transnational Corporations and Other Business Enterprises; Note A/73/163 by the Secretary General United Nations General Assembly; United Nations: New York, NY, USA, 2018.

81. Hansen, M.C.; Potapov, P.V.; Moore, R.; Hancher, M.; Turubanova, S.A.; Tyukavina, A.; Thau, D.; Stehman, S.V.; Goetz, S.J.; Loveland, T.R.; et al. High-Resolution Global Maps of 21st-Century Forest Cover Change. Science 2013, 342, 850. [CrossRef]

82. Chasek, P.; Akhtar-Schuster, M.; Orr, B.J.; Luise, A.; Rakoto Ratsimba, H.; Safriel, U. Land degradation neutrality: The sciencepolicy interface from the UNCCD to national implementation. Environ. Sci. Policy 2019, 92, 182-190. [CrossRef]

83. Sims, N.C.; England, J.R.; Newnham, G.J.; Alexander, S.; Green, C.; Minelli, S.; Held, A. Developing good practice guidance for estimating land degradation in the context of the United Nations Sustainable Development Goals. Environ. Sci. Policy 2019, 92, 349-355. [CrossRef]

84. Vitousek, P.M.; Mooney, H.A.; Lubchenco, J.; Melillo, J.M. Human Domination of Earth's Ecosystems. Science 1995, 277, 494-499. [CrossRef]

85. Pueyo, Y.; Beguería, S. Modelling the rate of secondary succession after farmland abandonment in a Mediterranean mountain area. Landsc. Urban Plan. 2007, 83, 245-254. [CrossRef]

86. Álvarez-Martínez, J.; Gómez-Villar, A.; Lasanta, T. The Use of Goats Grazing to Restore Pastures Invaded by Shrubs and Avoid Desertification: A Preliminary Case Study in the Spanish Cantabrian Mountains. L. Degrad. Dev. 2016, 27, 3-13. [CrossRef]

87. Ruiz-Mirazo, J.; Robles, A.B.; González-Rebollar, J.L. Two-year evaluation of fuelbreaks grazed by livestock in the wildfire prevention program in Andalusia (Spain). Agric. Ecosyst. Environ. 2011, 141, 13-22. [CrossRef] 
88. Moreira, F.; Rego, F.C.; Ferreira, P.G. Temporal (1958-1995) pattern of change in a cultural landscape of northwestern Portugal: Implications for fire occurrence. Landsc. Ecol. 2001, 16, 557-567. [CrossRef]

89. Puigdefábregas, J. Erosión y desertificación en España. Campo 1995, 132, 63-83.

90. Martínez-Valderrama, J.; Ibáñez, J.; Del Barrio, G.; Sanjuán, M.E.; Alcalá, F.J.; Martínez-Vicente, S.; Ruiz, A.; Puigdefábregas, J. Present and future of desertification in Spain: Implementation of a surveillance system to prevent land degradation. Sci. Total Environ. 2016, 563, 169-178. [CrossRef] [PubMed]

91. Pausas, J.G. Changes in Fire and Climate in the Eastern Iberian Peninsula (Mediterranean Basin). Clim. Change 2004, 63, 337-350. [CrossRef]

92. Syphard, A.; Radeloff, V.; Hawbaker, T.; Stewart, S. Conservation Threats Due to Human-Caused Increases in Fire Frequency in Mediterranean-Climate Ecosystems. Conserv. Biol. 2009, 23, 758-769. [CrossRef]

93. Zedler, P.H.; Gautier, C.R.; McMaster, G.S. Vegetation Change in Response to Extreme Events: The Effect of a Short Interval between Fires in California Chaparral and Coastal Scrub. Ecology 1983, 64, 809-818. [CrossRef]

94. Canadell, J.; López-Soria, L. Lignotuber Reserves Support Regrowth Following Clipping of Two Mediterranean Shrubs. Func. Ecol. 1998, 12, 31-38. [CrossRef]

95. Arianoutsou, M.; Vilà, M. Fire and invasive plant species in the mediterranean Basin. Isr. J. Ecol. Evol. 2012, 58, 195-203. [CrossRef]

96. Santana, V.M.; Baeza, M.J.; Marrs, R.H.; Vallejo, V.R. Old-field secondary succession in SE Spain: Can fire divert it? Plant Ecol. 2010, 211, 337-349. [CrossRef]

97. Hernández, L. El Planeta en Llamas. Propuesta Ibérica de WWF para la Prevención de Incendios; WWF: Madrid, Spain, 2020.

98. Alló, M.; Loureiro, M.L. Assessing preferences for wildfire prevention policies in Spain. For. Policy Econ. 2020, 115, 102145. [CrossRef]

99. Samaniego, L.; Thober, S.; Kumar, R.; Wanders, N.; Rakovec, O.; Pan, M.; Zink, M.; Sheffield, J.; Wood, E.F.; Marx, A. Anthropogenic warming exacerbates European soil moisture droughts. Nat. Clim. Chang. 2018, 8, 421-426. [CrossRef]

100. Cramer, W.; Guiot, J.; Fader, M.; Garrabou, J.; Gattuso, J.P.; Iglesias, A.; Lange, M.A.; Lionello, P.; Llasat, M.C.; Paz, S.; et al. Climate change and interconnected risks to sustainable development in the Mediterranean. Nat. Clim. Chang. 2018, 8, 972-980. [CrossRef]

101. MedECC. Risks Associated to Climate and Environmental Changes in the Mediterranean Region; MedECC: Marseille, France, 2019.

102. Ruffault, J.; Moron, V.; Trigo, R.M.; Curt, T. Objective identification of multiple large fire climatologies: An application to a Mediterranean ecosystem. Environ. Res. Lett. 2016, 11, 7. [CrossRef]

103. Turco, M.; Llasat, M.C.; von Hardenberg, J.; Provenzale, A. Climate change impacts on wildfires in a Mediterranean environment. Clim. Chang. 2014, 125, 369-380. [CrossRef]

104. Loepfe, L.; Martinez Vilalta, J.; Oliveres, J.; Piñol, J.; Lloret, F. Feedbacks between Fuel Reduction and Landscape Homogenisation Determine Fire Regimes in Three Mediterranean Areas. For. Ecol. Manag. 2010, 259, 2366-2374. [CrossRef]

105. Varela, E.; Górriz-Mifsud, E.; Ruiz-Mirazo, J.; López-i-Gelats, F. Payment for targeted grazing: Integrating local shepherds intowildfire prevention. Forests 2018, 9, 464. [CrossRef]

106. Krawchuk, M.A.; Moritz, M.A.; Parisien, M.-A.; Van Dorn, J.; Hayhoe, K. Global Pyrogeography: The Current and Future Distribution of Wildfire. PLoS ONE 2009, 4, e5102. [CrossRef]

107. Oxfam Smallholders at Risk. Monoculture Expansion, Land, Food and Livelihoods in Latin America. Oxfam Briefing Paper, 23 April 2014.

108. Himics, M.; Van Doorslaer, B.; Ciaian, P.; Shrestha, S. Increasing volatility of input costs in the EU agriculture. In Proceedings of the 123rd Seminar. European Association of Agricultural Economists, Dublin, Ireland, 23-24 February 2012.

109. Cochrane, W. Farm Prices: Myth and Reality; University of Minnesota Press: Minneapolis, MN, USA, 1958.

110. Sassenrath, G.F.; Heilman, P.; Luschei, E.; Bennett, G.L.; Fitzgerald, G.; Klesius, P.; Tracy, W.; Williford, J.R.; Zimba, P.V. Technology, complexity and change in agricultural production systems. Renew. Agric. Food Syst. 2008, 23, 285-295. [CrossRef]

111. The Observatory of Economic Complexity Product Trade Exporters and Importers. Soybeans. Available online: https://oec. world/en/profile/hs92/soybeans\#top (accessed on 29 January 2021). 